\title{
METODE SEJARAH DALAM PENELITIAN TRADISI UPACARA TIWAH \\ DESA KUALA KUAYAN KALIMANTAN TENGAH
}

\author{
Oleh : Ira Lukya Safira \\ Pendidikan Sejarah
}

\begin{abstract}
Abstrak
Tiwah merupakan upacara adat kematian suku Dayak Kalimantan Tengah. Tiwah yaitu bagian dari kepercayaan suku Dayak Ngaju, khususnya masyarakat yang masih menganut agama Hindu Kaharingan. Upacara adat tiwah bertujuan sebagai ritual untuk meluruskan perjalanan roh atau arwah menuju Lewu Tatau atau surga. Selain itu upacara tiwah dimaksudkan untuk melepas kesialan bagi keluarga almarhum yang ditinggalkan dari pengaruh-pengaruh buruk yang menimpa. Sejak kelahirannya, tiwah tetap hidup karena memiliki fungsi di masyarakat. Tradisi ini sangat perlu dikembagkan untuk mengangkat seni budaya suku Dayak dan nilai-nilai luhur nenek moyang agar tetap berurat berakar kuat dan kokoh di masyarakat serta menjalin persatuan kesatuan suku. Untuk menggali dinamika kehidupan tradisi upacara tiwah dalam suatu masyarakat suku Dayak akan sangat tepat dengan menggunakan metode sejarah. Metode ini dapat mengungkap bagaimana perjalanan sejarah tradisi upacara tiwah dari waktu ke waktu baik yang berkaitan dengan teks maupun konteknya.
\end{abstract}

\section{Pendahuluan}

Dalam proses penelitian, peneliti harus menentukan metode yang akan digunakan. Jika metode yang digunakan benar dan tepat maka penelitian akan selesai dengan baik. Menurut Mohamad Zaenal Arifin Anis (2015) sejarah sebagai ilmu mempunyai prosedur penelitian ilmiah, yaitu metodelogi. Ciri keilmuwan sejarah ditandai dengan apa yang disebut sebagai metode dan metodelogi sejarah. Metode sejarah merupakan metode yang dapat digunakan untuk mengungkapkan keberadaan peristiwa atau bentuk ritual tiwah tradisional masyarakat suku dayak. Ritual tiwah merupakan salah satu bentuk kesenian yang memiliki fungsi ekspresi religius, menghibur dan estetik dalam kehidupan masyarakat selain itu juga merupakan sajian yang berumur pendek, sehingga bisa saja hilang seiring berjalannya waktu. Oleh karena itu sangat 
penting dilakukan penelitian agar tidak kehilangan momen-momen penting dalam upacara tiwah. Tiwah dapat dipelajari dari perspektif sejarah, yang menggunakan metode sejarah untuk menjelaskan jalan hidup ritual Tiwah dalam masyarakat suku Dayak.

Metode sejarah sangat dipentingkan untuk menguak asal-usul sebuah peristiwa upacara tiwah. Setiap penelitian tradisi kebudayaan baik itu untuk kebutuhan skripsi, tesis, maupun disertasi, pada bagian latar belakang sudah tentu wajib mengungkapkan asal usul dari objek yang hendak diteliti. Maka dari itu jika peneliti memahami mengenai metode penelitian sejarah tentu pada bagian tersebut tidak akan asal-asalan. Umumnya peneliti percaya pada sumber-sumber yang belum teruji otentisitas dan kredibilitasnya. Oleh sebab itu untuk menghindari penulisan asal usul sebuah peristiwa upacara tiwah yang asal-asalan, maka perlu dipahami bagaimana metode penelitian sejarah dapat dilakukan sehingga peneliti yakin dengan apa yang dituangkan dalam mengungkap asal-usul sebuah peristiwa dalam karya ilmiahnya. Dengan metode sejarah, peristiwa upacara tiwah masyarakat suku dayak dapat diungkap bagaimana proses awal kelahirannya, perubahannya, pelaku-pelakunya, tempat dan waktu kejadiannya, serta alasan-alasan serta sebab akibat mengapa terjadi peristiwa tersebut.

\section{Penelitian Tradisi Upacara Tiwah Dengan Metode Sejarah}

Menurut (Sjamsuddin, 2007: 13) metode adalah suatu prosedur, atau berkaitan dengan suatu proses, atau teknologi sistematis, yang digunakan untuk menyelidiki suatu disiplin ilmu tertentu untuk memperoleh suatu objek penelitian (materi). Metode sejarah digunakan sebagai pedoman dalam melakukan penelitian tentang peristiwa sejarah dan permasalahannya. Metode ini merupakan alat untuk merekonstruksi peristiwa sejarah (catatan sejarah sebagai fakta masa lampau) menjadi sejarah sebagai cerita (catatan sejarah yang direkam). Untuk menjelaskan

peristiwa sejarah, pada prinsipnya bertujuan menjawab enam pertanyaan ( $5 \mathrm{~W}$ dan $1 \mathrm{H}$ ) guna mendeskripsikan secara detail keberadaan dan perubahan suatu objek (peristiwa atau wujud) dalam kehidupan manusia. Masalah dasar perlu dikembangkan berdasarkan masalah yang perlu diselesaikan. Hal ini untuk menghasilkan kejelasan (eksplanasi) mengenai arti penting (signifikansi) dan makna dari sebuah peristiwa. Adapun penelitian dengan menggunakan metode sejarah terdapat beberapa tahap yang wajib dilakukan yaitu: heuristik, kritik, interpretasi dan historiografi. 
1. Heuristik

Heuristik merupakan langkah awal sebagai sebuah kegiatan pencarian dan pengumpulan sumber-sumber yang berhubungan erat dengan objek penelitian. Pada tahap ini peneliti harus mengumpulkan sebanyak mungkin sumber untuk dijadikan bahan-bahan penelitian. Pada tahap ini juga, peneliti dituntut ketelatenan, kesabaran, dan ketelitian. Oleh karena itu perlu menyiapkan waktu, biaya, tenaga, serta pikiran untuk mencari dan mendapatkan sumber-sumber yang otentik sebagai bukti merangkai sebuah kisah sejarah. Adapun menurut (Gottschalk, 1975: 35-36; Kuntowidjoyo, 1995:94-96; Lubis, 2011:7 )sumber sejarah menurut bentuknya diklasifikasikan menjadi tiga di antaranya, sumber tertulis, sumber lisan, dan sumber benda atau artepak.

Sumber sejarah tertulis dibagi menjadi sumber resmi dan sumber tidak resmi. Dalam hubungan ini keresmian sumber ditentukan oleh hubungannya otoritas resmi pemegang kekuasaan negara. Termasuk sumber resmi adalah laporan atau arsip-arsip kenegaraan. Sedang sumber tidak resmi adalah sumber-sumber yang di luar itu semua. Buku-buku, surat kabar, majalah, babad, hikayat biografi, otobigrafi, memorial, surat-surat pribadi, artikel jurnal dan lain-lain yang termasuk sumber tidak resmi. Sebagai contoh sumber tertulis untuk mendapatkan informasi mengenai upacara tiwah pada zaman dahulu yaitu melalui artikel yang dipublis pada tahun 2003, dimana pada artikel tersebut menerangkan upacara tiwah yang diselenggarakan pada tahun 1991 didesa Buktiliti, Kalimantan Tengah.

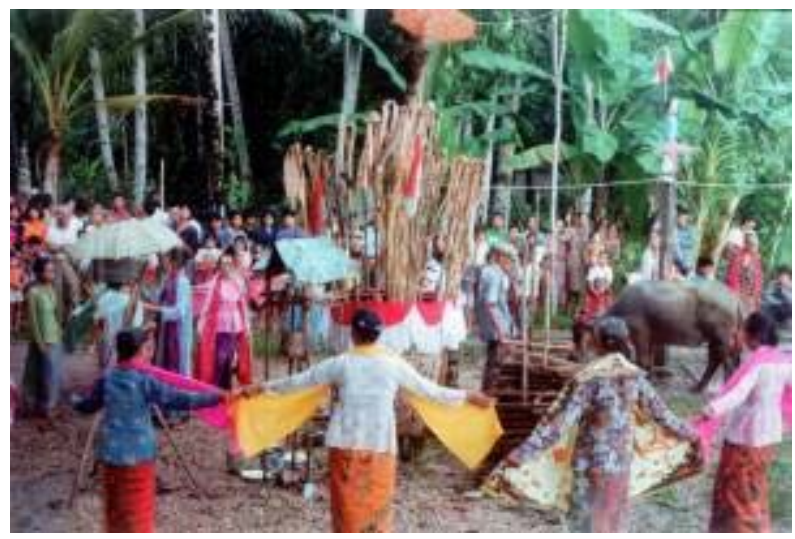

Sumber foto: Dari artikel Tempo tentang upacara Tiwah pada tahun 1991 (Sumber Tempo, 30 November tahun 1991, Dokumen penulis) 
Tulisan yang terdapat pada artikel Tempo yang ditulis oleh Alminhat tersebut merupakan peristiwa sejarah yang berkaitan dengan upacara tiwah di mana pada saat itu merupakan upacara tiwah yang diselenggarakan setelah terciptanya agama kaharingan pada tahun 1957. Sumber tertulis ini merupakan sumber otentik yang dapat dipergunakan untuk menjelaskan sejarah perkembangan upacara tiwah dari dulu hingga sekarang. Berdasarkan asal usulnya, sumber sejarah dapat digolongkan menjadi tiga yaitu sumber primer, skunder, dan tersier (Garraghan, 1946:107; Alfian, 2000:9; Lubis, 2011: 9-10) Peneliti harus mengumpulkan data dari saksi sejarah yang mengetahui tentang sebuah peristiwa yang menjadi objek penelitian. Contoh pada gambar di atas, merupakan salahsatu sumber primer, karena ditulis pada zamannya oleh saksi sejarah yaitu wartawan yang mengikuti acara tersebut.

Sedangkan sumber sejarah tidak tertulis dibedakan menjadi artefak, benda-benda dan sumber-sumber lisan. Termasuk sumber tidak tertulis adalah sumber lisan. Sumber lisan ini memiliki peranan yang tidak kalah pentingnya sebagai sumber sejarah. Dalam sejarah tradisional sumber sejarah lisan dapat berbentuk cerita rakyat (folklore), mitos, legenda, cerita penglipur lara dan silsilah atau genealogi. Seperti yang diterangkan oleh Mohamad Zaenal Arifin Anis (2015:58) sumber sejarah berasal dari jejek atau kesaksian yang ditinggalkan dalam peristiwa, kemudian ditafsirkan oleh sejarawan sehingga dapat menceritakan tentang realitas masalalu. Dalam konteks ini termasuk tradisi lisan yang menjadi memori kolektif masyarakat yang dapat dijadikan sumber sejarah yang digunakan oleh sejarawan.

Dewasa ini kedudukan sejarah lisan semakin menjadi penting. Sumber sejarah lisan bersifat komplementer terhadap sumber-sumber tertulis. Melalui wawancara sumbersumber lisan dapat diungkap dari para pelaku-pelaku sejarah. Bahkan peristiwa-peristiwa sejarah yang belum jelas betul persoalannya sering dapat diperjelas justru berdasarkan pengungkapan sumber-sumber sejarah lisan. Adapun untuk sumber lisan yang menjadi data sumber primer dalam peristiwa upacara tiwah yaitu masyarakat maupun tokoh-tokoh yang saat itu terlibat dan menyaksikan langsung proses upacara tiwah. 


\section{Kritik}

Kritik sumber merupakan salah satu langkah yang harus dilakukan yaitu mengkritisi dari sumber-sumber yang telah dikumpulkan untuk dibuktikan otentisitas dan kredibilitasnya. Dalam kritik ini diperlukan kritik internal maupun eksternal. Tujuan dilakukan kritik adalah untuk mencari kebenaran (truth), di mana peneliti harus dapat membedakan apa yang benar dan tidak benar atau palsu, apa yang mungkin dan apa yang meragukan atau mustahil. Peneliti harus mengerahkan segala kemampuan pikirannya bahkan juga sering kali harus menggabungkan antara pengetahuan, sikap ragu atau skeptis, percaya begitu saja, menggunakan akal sehat dan melakukan tebakan. Fungsi kritik untuk dapat mempertanggungjawabkan temuannya untuk dapat dipercaya masyarakat luas. Kritik sumber ini dilakukan terhadap sumber pertama yaitu pengujian mengenai kebenaran atau ketepatan (akurasi) dari sumber tersebut (Sjamsuddin, 2007: 132).

Sumber terlebih dahulu harus dikritik melalui kritik eksternal dan krtitik internal. Kritik eksternal adalah suatu penelitian atas asa usul dari sumber, suatu pemeriksaaan atas catatan atau peninggalan untuk mendapatkan semua informasi yang mungkin, dan untuk mengetahui apakah pada suatu waktu sumber tersebut telah diubah oleh orang tertentu atau tidak. Kritik eksternal dilakukan untuk memverifikasi atau menguji terhadap aspek-aspek luar dari sumber sejarah yang telah dikumpulkan. Fungsi dari kritik eksternal ini adalah untuk memeriksa sumber sejarah demi menegakkan sedapat mungkin tentang otentisitas dan integritas dari sumber tersebut (Sjamsuddin, 2007: 135, 136).

Contoh ketika peneliti menemukan sebuah rekaman atau photo pada saat proses upacara tiwah yang menurut keterangan narasumber bahwa upacara tersebut dibuat pada abad-14 misalnya. Maka peneliti perlu mencari ahli bidang perekaman dan meneliti tentang keberadaan alat rekam pada abad tersebut, sehingga bila ditemukan fakta bahwa abad ke14 belum ada alat rekam di Indonesia maka data tersebut tidak kredible.

3. Interpretasi

Interpretasi atau sintesis, merupakan kegiatan untuk menafsirkan fakta-fakta juga menentukan makna dan saling berhubungan daripada fakta-fakta yang diperoleh. Dengan kata lain interpretasi dibuat berdasarkan informasi yang diberikan oleh jejak-jejak masa lampau tersebut untuk masuk pada suasana masa lampau yang diteliti. Interpretasi 
memiliki tingkat kerawanan yang tinggi, karena di sini berhubungan erat dengan imajinasi si penulis itu sendiri, sehingga orang banyak berargumen bahwa di sinilah biang subjektivitas. Tanpa penafsiran sejarawan, data tidak dapat berbicara. Untuk itu pada tahap ini diperlukan kejujuran dari peneliti di mana mengungkapnya sesuai dengan fakta.

Dalam interpretasi diperlukan kecermatan dalam menghubungkan sebuah fakta satu dengan fakta lain sehingga peneliti dapat menceritakan kembali untuk mengungkapkan sebuah peristiwa sejarah. Sebagai contoh dalam interpretasi terhadap asalusul upacara tiwah. Ketika peneliti menemukan fakta-fakta bahwa telah terjadi sebuah upacara tiwah bahkan pada zaman dahulu ketika sebelum mengenal tulisan, yang kemudian masyarakat dayak ngaju mewariskan kebudayaan nenek moyangnya tersebut. Maka dapat diinterpretasikan bahwa proses pewarisan ini sudah turun-temurun sampai pada tahap terciptanya agama kaharingan, yang kemudian dari budaya nenek moyang tersebut diintegrasikan dengan kepercayaan kaharingan.

\section{Historiografi}

Historiografi adalah menyampaikan hasil rekonstruksi imajinatif daripada masa lampau itu sesuai dengan jejak-jejaknya yang kemudian dituangkan ke dalam sebuah karya tulis menjadi sebuah kisah sejarah. Oleh sebab itu, kemampuan dalam menulis sangat dibutuhkan, dalam arti kemahiran art of writing tidak boleh diabaikan (Herlina, 2008: 1516). Pada tahapan historiografi, yang harus dituangkan dalam tulisan merupakan hasil dari penafsiran dari fakta-fakta itu menjadi sebuah kisah sejarah yang selaras. Historiografi dimengerti sebagai "seni penulisan sejarah". Bukan dalam pemakaian secara luas sebagai sastra sejarah atau isi kumpulan tulisan-tulisan sejarah termasuk kaidah yang sama. Suatu studi mengenai metode-metode pekerjaan dari sejarawan terungkap dalam hasil tulisannya, adalah suatu tujuan pelajaran mengenai nilai.Penulisan meupakan puncak segala-galanya. Sebab apa yang dituliskan itulah sejarah-yaitu histoireresite, sejarah sebagaimana ia dikisahkan, yang mencoba menangkap dan memahami histoire-resite yaitu sejarah sebagaimana terjadinya. Hasil dari pengerjaan studi sejarah yang akademis atau kritis ini, yang berusaha sejauh mungkin mencari "kebenaran" histori. Menurut Menurut Mohamad Zaenal Arifin Anis (2015) ketika sejarawan menghasilkan karya sejarahnya atau dikenal dengan sebutan historiografi, maka sejarawan akan memberikan ruang kebebasan 
menafsirkan kepada para pembacanya. Dalam arti kata karyanya telah mampu menangkap jiwa zaman yang menjadi subjek penelitiannya yang tentunya berbeda dengan jiwa masa kini tetapi memiliki kesinambungan.

\section{Penutup}

Tradisi upacara tiwah masih banyak hal-hal yang perlu diteliti. Penulisan atau penelitian tentang tradisi kebudayaan khususnya di Indonesia masih harus dilakukan, oleh sebab itu hal yang sangat dipentingkan adalah bagaimana secara bertahap penulisan sejarah kebudayaan ini harus dilakukan. Sudah terdapat beberapa penulis dan penelitian sejarah kebudayaan namun bila dibandingkan dengan objek yang ada dalam kebudayaan ternyata belum seimbang. Di sinilah pentingnya metode sejarah digunakan untuk meungkapkan peristiwa-peristiwa budaya atau awal mula dan perjalanan bentuk-bentuk dari tradisi kebudayaan itu sendiri.

\section{Daftar Pustaka}

Garraghan, J. Gilbert. 1948. A Guide To Historical Method, New York: Fordham University Press Gottschalk, Louis. 1975. Mengerti Sejarah (Pengantar Metode Sejarah), Terjemahan. Nugroho Notosutanto, Jakarta: Universitas Indonesia.

Herlina, Nina. 2008. Metode Sejarah, Bandung: Satya Historika.

Kuntowijoyo. 2003. Metodologi Sejarah, Edisi kedua, Yogyakarta: Tiara Wacana.

Lubis, Nina Herlina. 1998. Kehidupan kaum Menak Priangan 1800-1942. Bandung: Pusat Informasi Kebudayaan Sunda.

Anis, M Zenal Arifin. 2015. "Sejarah Bukan Warisan Melainkan Pembelajaran”. Prosiding Seminar Nasional dan Pertemuan Asosiasi Pendidik dan Peneliti Sejarah. Banjarmasin.

Sjamsudin, Helius. 2007. Metodologi Sejarah, Yogyakarta: Ombak. 